\title{
PENENTUAN KUALITAS DEGUMMED BLEACHED PALM OIL (DBPO)DAN \\ REFINED BLEACHED DEODORIZED PALM OIL (RBDPO) DENGAN PEMBERIAN BLEACHINGEARTH PADA SKALA INDUSTRI
}

\section{QUALITY DETERMINATION OF DEGUMMED BLEACHED PALM OIL (DBPO)AND REFINED BLEACHED DEODORIZED PALM OIL(RBDPO)BY GIVING BLEACHING EARTHON INDUSTRIAL SCALE}

\author{
Hesty Heryani \\ Jurusan Teknologi Industri Pertanian, Fakultas Pertanian, Universitas Lambung Mangkurat \\ Jl. Ahmad Yani. Km. 36, Banjarbaru 70714, Indonesia \\ e-mail: hheryani@ulm.ac.id \\ Makalah: Diterima 1 September 2018; Diperbaiki 2 Januari 2019; Disetujui 15 Januari 2019
}

\begin{abstract}
Bleaching earth is a material absorbing various impurities bounded during the degumming process. Its other function is as $\mathrm{CPO}$ colour bleaching material in bleaching process. The study was conducted to determine the efficiency of the production process at the best concentration of giving bleaching earth toquality of degummed bleached palm oil (DBPO) and refined bleached deodorized palm oil (RBDPO), during fractionation. The quality parameters observed were free fatty acid (FFA), colour, cloud point and iodine number. The use of earth bleaching concentration ranges was set from $0.6 \%$ to $1.0 \%$. Production process efficiency was measured on the basis of maximum RBDPO output and minimum input at a capacity of 2,000 tons per day with a flow rate of $41.6 \mathrm{t} / \mathrm{h}$. The best results were obtained with FFA DBPO values of $\leq 4.5 \%$, FFA RBDPO of $0.051 \%-0.053 \%$, colour of DBPO of 19R-21R, colour of RBDPO 2.25R-2.70R, the use of bleaching earth 0.8\% - 0.9\%. At this concentration cloud point DBPO was $2.15 \mathrm{ppm}$ and $1.95 \mathrm{ppm}$. For the RBDPO cloud point at the same bleaching earth, the concentration was 2.47 and $1.76 \mathrm{ppm}$. The measurement results of iodine value were at $51,794 \mathrm{mg} \mathrm{I}_{2} / \mathrm{g}$ to $52,775 \mathrm{mg} \mathrm{I}_{2} / \mathrm{g}$, meaning the value was still in the industry RBDPO quality standard of 50 - 55 mg $I_{2} / g$. Addition of $0.8 \%$ - 0.9\% bleaching earth could maintain the quality of DBPO and RBDPO with the efficient production process reaching $95.51 \%$.
\end{abstract}

Keywords: cloud point, degumming, flow rate, free fatty acid, iodine number

\section{ABSTRAK}

Bleaching earth merupakan bahan yang dapat mengabsorbsi berbagai pengotor yang terikat saat proses degumming. Fungsi lain dari bleaching earth digunakan sebagai bahan pemucat warna CPO pada proses bleaching. Penelitian dilakukan untuk mengetahui efisiensi proses produksi pada konsentrasi terbaik pemberian bleaching earth terhadap kualitas degummed bleached palm oil (DBPO) dan refined bleached deodorized palm oil (RBDPO) saat fraksinasi. Parameter mutu yang diamati adalah asam lemak bebas (FFA), warna, cloud point dan bilangan iod. Penggunaan konsentrasi bleaching earth ditetapkan dari 0,6\% hingga 1,0\%. Efisiensi proses produksi diukur atas dasar output RBDPO maksimum dan input minimum pada kapasitas 2.000 ton per haridengan flow rate 41,6 ton per jam. Hasil terbaik yang diperoleh dengan nilai FFA DBPO $\leq 4,5 \%$, FFA RBDPO 0,051\% - 0,053\%, warna DBPO 19R - 21R, warna RBDPO 2,25R - 2,70R yaitu pada penggunaan bleaching earth0,8\% - 0,9\%. Pada konsentrasi tersebut cloud point DBPO yaitu 2,15 ppm dan 1,95 ppm. Untuk cloud point RBDPO pada konsentrasi bleaching earth yang sama yaitu 2,47 ppm dan 1,76 ppm. Hasil pengukuran bilangan iod berada pada $51,794 \mathrm{mg} \mathrm{I} / \mathrm{g}$ hingga $52,775 \mathrm{mg} \mathrm{I} / \mathrm{g}$ yang berarti bahwa nilai tersebut memenuhi standar kualitas RBDPO industri yaitu 50 - $55 \mathrm{mg} \mathrm{I} / \mathrm{g}$. Penambahan $0,8 \%-0,9 \%$ bleaching earth dapat menjaga kualitas dari DBPO dan RBDPO dengan efisien proses produksi mencapai 95,51\%.

Kata kunci:cloud point, degumming, flow rate, asam lemak bebas, bilangan iod

\section{PENDAHULUAN}

Pada proses pemurnian minyak sawit skala industri, biasanya proses degumming dan bleaching dilakukan sekaligus untuk mengefisienkan proses produksi. Proses degumming bertujuan untuk menghilangkan komponen fosfolipid yang terdiri dari fosfatida, protein, residu, karbohidrat, air serta resin yang menimbulkan warna gelap pada crude palm oil (CPO) tanpa mengurangi jumlah asam lemak yang terkandung di dalamnya sedangkan bleaching diutamakan untuk memperbaiki warna minyak sesuai standar mutu (Heryani dan Nugroho, 2017).

Warna merupakan parameter utama dalam penentuan kualitas minyak dan digunakan sebagai dasar dalam penentuan apakah minyak tersebut diterima atau tidak dalam dunia perdagangan. Warna 
CPO yang gelap menandakan kualitas minyak yang rendah, sehingga perlu dilakukan pencegahan dengan menambahkan bleachig earthdalam proses Degumming dan Bleaching (Low, Lee, dan Kong, 1998). Kemampuan untuk memucatkan tergantung pada perbandingan antara komponen $\mathrm{SiO}_{2}$ dan $\mathrm{Al}_{2} \mathrm{O}_{3}$ yang terdapat dalam bleaching earth tersebut yang dapat menyerap pigmen pada minyak dengan baik (Tsai et al., 2002).

Bleaching earth juga dapat berfungsi sebagai adsorben untuk mendapatkan standar mutu warna bleaching palm oil (BPO) pada industri refinery berbasis CPO. Untuk jenis bleaching earth yang sama diperlukan konsentrasi optimal untuk mempertahankan kualitas degumming bleaching palm oil (DBPO) dan refined bleached deodorize palm oil (RBDPO). Jenis bleachig earthyang digunakan adalah bentonit yang juga berperan sebagai bleaching agent. Secara fisik bleachig earth yang digunakan mempunyai ciri warna putih tulang dan berbentuk serbuk. Jenis ini digunakan dalam proses refinery sebagai penyerap bahan pengotor yang terdapat pada crude palm oil (CPO). Proses pemucatan minyak sawit dengan menambahkan bleaching earth pada skala industri biasanya berlangsung selama 30 menit pada temperatur $100-$ $130^{\circ} \mathrm{C}$ (Heryani dan Nugroho, 2017). Proses pemurnian diperlukan untuk menghilangkan rasa serta bau dengan cara pemanasan. Demikian pula dengan warna yang tidak menariksehingga dapat memperpanjang masa simpan minyak.

Untuk kuantitas adsorben yang digunakan umumnya beragam, ditentukan oleh keaktifan dari bahan dan sifat ataupun pencirinya. Faktor yang juga menentukan adalah jenis minyak, intensitas warna minyak dan warna yang diinginkan dari minyak hasil pemucatan. Parameter proses pemucatan seperti suhu dan waktu kontak juga mempengaruhi jumlah adsorben yang dibutuhkan. Dalam kajian ini kedua variabel tersebut bersifat tetap. Kebaruan dari penelitian adalah pada sisi skala proses produksi yaitu 2.000 ton per hari dengan spesifikasi awal CPO dan penggunaan aktivasi asam yang berbeda dari beberapa riset lain yang serupa.

Tujuan penelitian yang merupakan hasil observasi lapangan pada beberapa periode tertentu ini adalah untuk mengetahui efisiensi proses produksi dan konsentrasi terbaik pemberian bleaching earth terhadap kualitas degummed bleached palm oil (DBPO) dan refined bleached deodorized palm oil (RBDPO) saat fraksinasi.

\section{BAHAN DAN METODE}

\section{Bahan dan Alat}

Bahan dan alat yang digunakan mengacu pada spesifikasi industri sejenis. Khusus untuk bahan meliputi $\mathrm{CPO}$, bleaching earth $\left(\mathrm{SiO}_{2} \mathrm{~min}\right.$ $58 \%$ ), asam fosfat (85\%), asam sitrat (99,5\%), DBPO dan RBDPO. Untuk peralatan sesuai dengan tahapan operasional pada industri refinery kapasitas 2.000 ton per hari. Peralatan yang digunakan adalah oil feed pump, dryer pump, slurry pump, plate heat exchanger, start up heater, dryer, dynamix statix, retention vessel, bleacher dan buffer vessel. Untuk proses filtrasi menggunakan Niagara filter, bag filter dan filtrate receiver. Pada proses deodorizing, peralatan yang diperlukan seperti bleached oil pump, RBD oil transfer pump, fatty acid circulating pump, $R B D$ inline pump,catridge filter, falling film heat exchanger, final oil heater, deodorizer, pre stripper, plate heat exchanger, high pressure boiler, final oil cooler, bag filter, PFAD tank, plate heat exchanger, PFAD storage tank dan RBDPO storage tank. Untuk proses filtrasi menggunakan Niagara filter, bag filter dan filtrate receiver. Alat pengukuran yang diperlukan berupa $\mathrm{pH}$ meter, spektrofotometer, MP80 melting point system, Lovibond model E tintometer, seperangkat alat titrasi, water bath, dan beberapa alat ukur manual serta alat gelas lainnya.

\section{Metode}

Penelitian dilaksanakan di PT. X merupakan Mitra Industri yang sudah lama bergerak di bidang agroindustri kelapa sawit di Kalimantan. Metode yang dikembangkan dimulai dari preparasi, standarisasi bahan utama (CPO) serta dasar penetapan konsentrasi bleaching earth dan penggunaan bahan tambahan, dilanjutkan dengan analisis data, termasuk di dalamnya penghitungan efisiensi proses produksi.

\section{Preparasi}

Preparasi bertujuan agar CPO yang berada di tangki penampungan (storage tank) tersedia cukup untuk setiap batch proses fraksinasi dalam menghasilkan DBPO dan RDBPO. Di sisi lain dengan preparasi diharapkan pengecekan parameter mutu bahan (CPO) seperti FFA, kadar air, bilangan iod dan DOBI memenuhi persyaratan awal sebelum masuk ke proses fraksinasi.

\section{Standarisasi Bahan Baku CPO}

Untuk industri refinery umumnya menerapkan standarisasi khususnya untuk bahan baku yang digunakan dalam proses lanjut. Spesifikasi CPO yang digunakan pada stasiun fraksinasi diantaranya asam palmitat maksimum 5\%, kadar air maksimum $0,5 \%$, bilangan iod minimal 50 $\mathrm{mg} \mathrm{I}_{2} / \mathrm{g}$ serta deterioration of bleachability index (DOBI) minimal 2. Pengukuran DOBI dilakukan dengan memperhatikan absorbansi pada panjang gelombang $268 \mathrm{~nm}$ dan $446 \mathrm{~nm}$.

\section{Penentuan Konsentrasi Bleaching Earth dan Penggunaan Bahan Tambahan}

Bleaching earth yang digunakan memiliki fungsi ganda, selain sebagai bahan pemucat juga sebagai adsorben. Di industri bleaching earth dikenal dengan bentonit. Montmorillonit dalam 
bentonit berwujud mineral liat yang dapat mengembang dan mengerut yang tergolong ke dalam kelompok smektit serta mempunyai komposisi kimia yang beragam. Kemampuan untuk mengembangmengerut serta adanya muatan negatif yang cukup besar memungkinkan bahan mineral tersebut dapat mengadsorbsi ion-ion logam dan kation-kation organik (Tan, 1993).

Spesifikasi bleaching earth yang digunakan adalah kadar air maksimal 15\%, pH dengan $10 \%$ larutan suspensi berkisar 6,5 - 8,5, densitas $0,5-$ $0,65 \mathrm{~g} / \mathrm{L}$, kandungan $\mathrm{SiO}_{2}$ minimal $58 \%$, kenampakan warna coklat muda keabu-abuan. Penentuan konsentrasi bleaching earth didasarkan pada kemampuan untuk memucatkan yaitu perbandingan antara komponen $\mathrm{SiO}_{2}$ dan $\mathrm{Al}_{2} \mathrm{O}_{3}$ yang terdapat dalam bleaching earth tersebut sehingga dapat menyerap pigmen pada minyak dengan baik (Tsai et al., 2002). Hal tersebut sejalan dengan penelitian Young (1987) yang menggunakan bleaching earth pada rentang 0,5\%-2,0\%.

Bahan tambahan yang digunakan berupa asam sitrat dan asam fosfat. Asam sitrat memiliki peran sebagai bahan penolong saat pemurnian minyak sawit. Spesifikasi bahan sesuai dengan standar industri untuk asam sitrat yang berwujud granular (powder) harus memiliki kemurnian 99,5\%, kadar air maksimum 0,5\%, keberadaan timbal dan arsen masing-masing tidak melebihi 5 ppm dan 1 ppm, bahkan diupayakan untuk kandungan arsen tidak ada.

Asam fosfat digunakan untuk mempermudah proses penghilangan getah/gum maupun kotoran lain yang terikut di unit Refinery. Spesifikasi asam fosfat yang dipergunakan industri berwujud cairan, kadar minimal $85 \%$, keberadaan logam berat seperti $\mathrm{Pb}$ maksimal $10 \mathrm{ppm}$, arsen tidak lebih 5 ppm dan fluorida juga tidak lebih 10 ppm.

\section{Analisis Data}

Data yang digunakan berasal dari 3 batch operasi dan diasumsikan sebagai ulangan pada masing-masing parameter kualitas produk yaitu analisis kadar FFA dan warna menggunakan metode American Oil Chemists' Society (AOCS) (1998). Analisis cloud point menggunakan MP80 melting point system dan untuk penentuan bilangan iod menggunakan metodeWijs.

Untuk efisiensi proses produksi dihitung dengan memperhatikan rasio antara input dengan output, atau perbandingan antara input yang digunakan dengan hasil outputnya. Efisiensi dievaluasi atas dasar penilaian-penilaian relatif, membandingkan antara masukkan dan keluaran yang ada. Pada industri refinery umumnya, efisiensi diukur atas dasar output RBDPO yang maksimum dan input yang minimum pada kapasitas 2.000 ton per hari. Optimasi proses berlangsung pada flow rate 41,6 ton per jam.

\section{HASIL DAN PEMBAHASAN}

\section{Kualitas CPO}

Bahan baku utama berupa crude palm oil (CPO) harus memiliki kualifikasi standar sebelum dialirkan ke dryer. Kadar air yang tinggi berakibat pada gum dan pengotor lainnya tidak dapat dijerap dengan baik oleh bleaching earth. Demikian pula halnya dengan bilangan iod yang relatif rendah $(<50$ mg $\mathrm{I}_{2} / \mathrm{g}$ ) menunjukkan derajat ketidakjenuhan dari minyak yang juga mempengaruhi kadar asam lemak bebas yang semakin meningkat.

Deterioration of bleachability index (DOBI) merupakan bagian dari indikator baik tidaknya kualitas CPO yang digunakan sebagai bahan baku, jika angka DOBI < 2, akan berpengaruh pada proses bleaching karena karoten akan sulit dihilangkan. Jika kisaran DOBI pada 2,5 - 4,0 mengindikasikan bahwa CPO memiliki kualitas yang baik (Silva et al., 2014).

Beberapa hal yang mengakibatkan rendahnya nilai DOBI seperti persentase buah tidak matang terlalu tinggi, proses menunggu sebelum diolah yang terlalu lama. Adanya peluang kontaminasi minyak CPO dengan kondensat dari proses sterilisasi serta terkontaminan dengan sludge oil yang teroksidasi, juga dapat dijadikan upaya kendali awal agar CPO tetap berada pada standar spesifikasi kualitas bahan baku.

\section{Hasil Fraksinasi}

Proses Degumming dan Bleaching

Pada Gambar 1 dijelaskan penggunaan bahan utama yaitu CPO dan bahan tambahan lainnya berupa asam fosfat atau asam sitrat. Proses Degumming berlangsung didalam dynamix mixeru ntuk menghilangkan getah/gum, tracemetal, kadar air dan pengotor-pengotor yang terkandung di dalam CPO meggunakan asam fosfat $\left(\mathrm{H}_{3} \mathrm{PO}_{4}\right)$. Hal tersebut sejalan dengan hasil penelitian dari Didi et al. (2009) dan Farihahusnah et al. (2011) yang memperlihatkan kinerja bahwa bleaching merupakan tahap kritis dan sangat penting pada proses refinery minyak, dimana proses adsorbsi menggunakan adsorben untuk meningkatkan mutu terkait kenampakan, bau, rasa dan stabilitas dari produk akhir saat menghilangkan warna dan beberapa penyebab munculnya pigmen dari minyak.

Selanjutnya proses bleaching untuk menghilangkan warna pekat dilakukan secara terusmenerus pada suhu minyak $40-120^{\circ} \mathrm{C}$ serta dalam keadaan vakum maksimum 160 mbar. Semakin tinggi aktifitas bleaching earth, maka semakin mudah disaring. Hasil observasi lapangan diketahui bahwa CPO berwarna jingga sampai kemerahmerahan, setelah proses adsorbsi berwarna kuning jernih. 


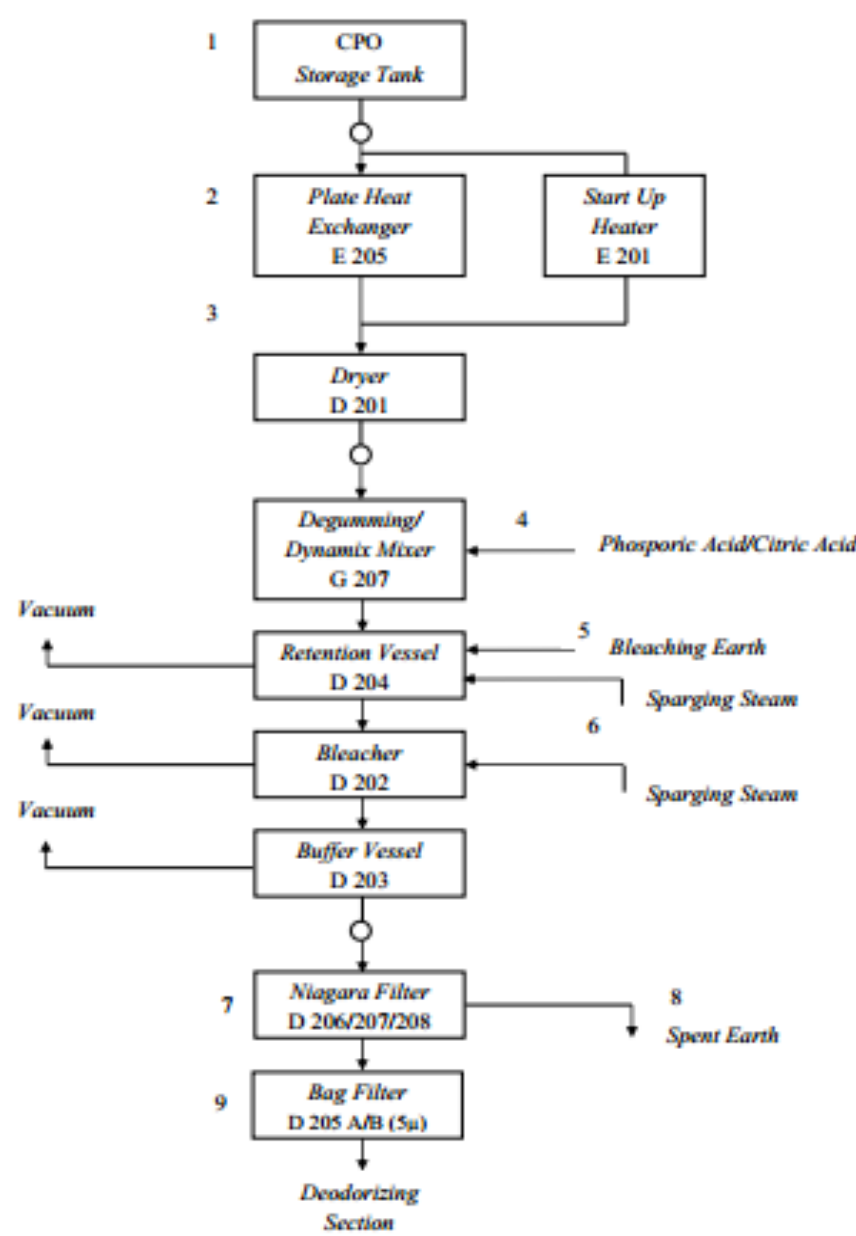

Gambar 1. Diagram alir dari proses degumming dan bleaching

Hal ini disebabkan fungsi adsorben yang menyerap warna, asam lemak, dan pengotor lain dalam minyak sehingga dapat mempengaruhi kualitas warna minyak yang dihasilkan(Silva et al., 2014). Setelah proses degumming dan bleaching selesai, sebelum deodorizing section perlu dilakukan proses filtrasi terlebih dahulu

Proses Filtrasi

Proses filtrasi merupakan proses penyaringan dengan tujuan agar minyak terbebas dari partikel-partikel bleaching earth. Hasil observasi menunjukkan minyak sawit saat berlangsung proses filtrasi dilakukan secara kontinyu selama 160 menit. Setelah proses penyaringan berjalan selama 160 menit maka aliran minyak akan berhenti secara otomatis. Hal ini juga merupakan pertanda bahwa kapasitas minyak pada tangki Niagara filter telah penuh. Minyak yang telah terfilter kemudian di filtrasi kembali menggunakan bag filter yang berukuran 5 mikron yang selanjutnya ditampung di tangki penyimpanan DBPO kemudian akan dilanjutkan dengan tahapan deodorisasi.

\section{Proses Deodorizing}

Prosesdeodorisasi merupakan proses penghilangan asam lemak bebas dan komponen penyebab bau tidak sedap seperti peroksida, keton dan senyawa hasil oksidasi lemak lainnya(Copeland dan Maurice, 2005). Hasil observasi menunjukkan proses berlangsung secara kontinyu pada suhu 95 $268^{\circ} \mathrm{C}$. Proses berlangsung di dalam deodorizer berlangsung pada kondisi vakum tekanan maksimum 6 mbar. Produk RBDPO yang dihasilkan dari proses sebagaimana Gambar 2, mengalami proses penyaringan/filtrasi terakhir di bag filter berukuran 10 mikron dimana proses ini merupakan CCP (critical control point) sebelum RBDPO ditransfer ke RBDPO storage tank (Heryani dan Nugroho, 2017). Hasil yang diperoleh untuk masing-masing parameter pengamatan yaitu kadar air, FFA, warna, cloud point maupun bilangan iod pada DBPO maupun RBDPO disajikan pada bagian analisis kualitas produk.

\section{Analisis Kualitas Produk}

Konsentrasi Bleaching Earth Terhadap FFA Produk Penggunaan konsentrasi bleaching earth mengacu pada penelitian Young (1987) yang menyatakan bahwa proses pemucatan CPO menggunakan bleaching earth pada konsentrasi $0,5 \%$ hingga 2,0\% dari massa CPO. Atas dasar hal tersebut disertai dengan memperhatikan data operasi yang ada, maka konsentrasi yang digunakan adalah $0,6 \%-1,0 \%$. 
Hasil yang diperoleh pada konsentrasi bleaching earth 0,8\%-0,9\%, rata-rata FFA DBPO yang diperoleh tidak melebihi $4,5 \%$, sementara pada konsentrasi lainnya angka FFA melebihi nilai tersebut (Gambar 3a). Pada Gambar 3a memperlihatkan penggunaan konsentrasi bleaching earth terbaik pada $0,8 \%-0,9 \%$ dengan rata-rata FFA masing-masing 4,18\% (SD $\pm 0,07$ ) dan $4,08 \%$ (SD $\pm 0,07$ ). Kinerja kualitas produksi tersebut sesuai dengan SNI 01-008-2006 dan standar FFA DBPO dari perusahaan maksimal 4,5\%. Di sisi lain mengacu ketentuan industri yang relevan dengan SNI masih direkomendasikan hingga mencapai $5 \%$.

Untuk hasil pada Gambar 3b memperlihatkan penggunaan konsentrasi bleaching earth terbaik pada $0,8 \%-0,9 \%$ dengan rata-rata FFA RBDPO masing-masing 0,051\% (SD $\pm 0,007$ ) dan $0,053 \%$ (SD $\pm 0,004)$. Hasil yang diperoleh sesuai dengan ketentuan di industri FFA RBDPO maksimal $0,1 \%$.

Menurut Ismail et al. (2018), FFA hasil degumming dan bleaching akan mungkin masih mengalami peningkatan karena dipengaruhi oleh suhu proses pengolahan DBPO dan proses oksidasi serta hidrolisis enzim, sehingga menghasilkan asam lemak bebas dangliserol, walaupun enzim tersebut seperti lipase telah dinonaktifkan sebelumnya dengan adanya proses pemanasan.

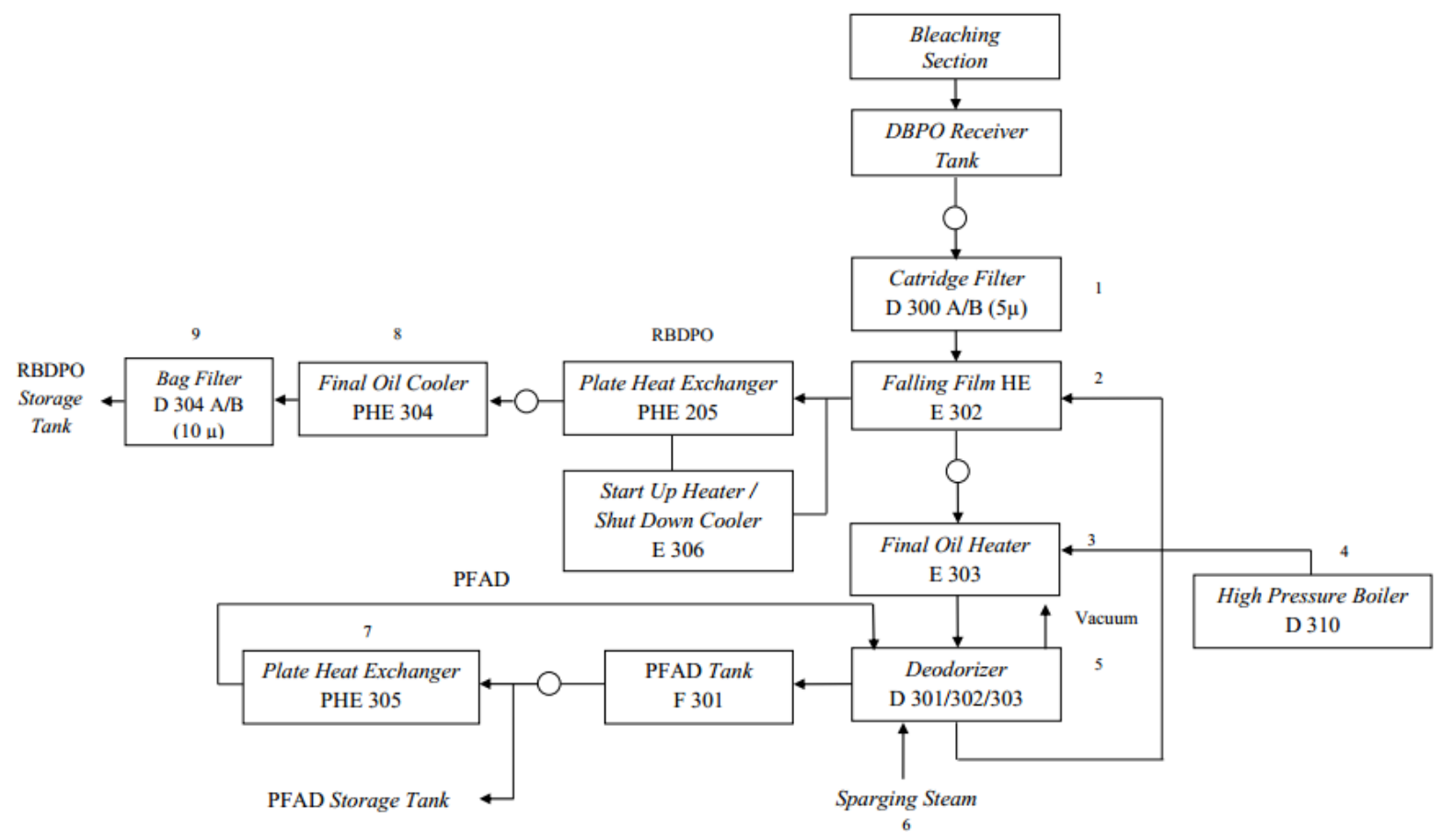

Gambar 2. Diagram alir proses deodorizing

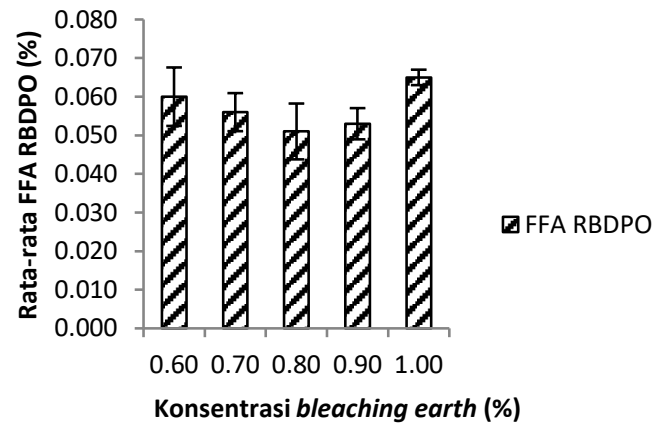

(a)

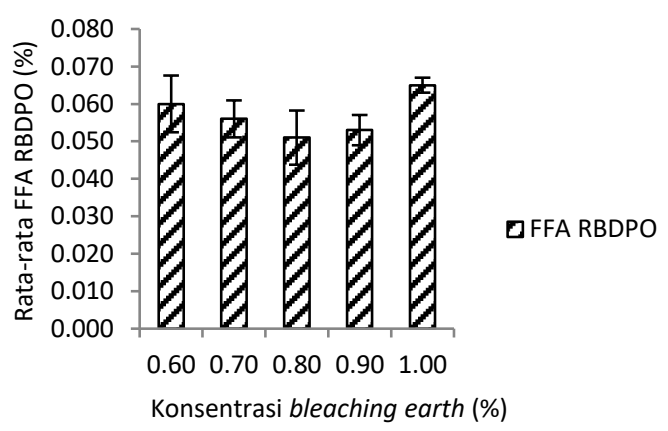

(b)

Gambar 3a. Efektifitas bleaching earth terhadap kandungan (a) FFA DBPO, (b) FFA RBDPO 


\section{Konsentrasi Bleaching Earth Terhadap Warna Produk}

Minyak sawit merupakan salah satu minyak nabati yang sulit dipucatkan karena mengandung karoten dalam jumlah besar yaitu $500-700 \mathrm{mg} / \mathrm{kg}$. Hal inilah yang memunculkan warna orange gelap (Gee, 2007). Karoten pada CPO dapat bereaksi dengan senyawa radikal melalui beberapa cara termasuk kemampuannya yang bisa menambahkan senyawa radikal lain dan dapat mentransfer elektron (Bonnie dan Choo, 1999).

Pada CPO (crude palm oil) standar warna yang telah ditetapkan untuk produksi minyak DBPO (degumming bleaching palm oil) adalah maksimum 19/19 (Red/Yellow) (SNI 01 -008 -2006), tetapi untuk industri masih memberikan rentang pada 1922. Sementara untuk standard produksi minyak RBDPO (rafined bleached deodorized palm oil) adalah maksimum $3 \mathrm{R}$.

Hasil yang diperoleh sebagaimana tersaji pada Gambar 4, memperlihatkan konsentrasi bleaching earth yang digunakan terhadap rata-rata pada 3 batch operasi untuk warna DBPO dengan kandungan maksimal tidak melebihi standar yaitu 19R - 21R. Sementara untuk standar warna DBPO ditetapkan $22 \mathrm{R}$. RBDPO memiliki standar warna pada skala industri $\leq 3 R$. Hasil yang diperoleh pada rentang 2,25R - 2,70R. Hal ini berarti untuk warna,baik DBPO maupun RBDPO telah memenuhi standar pada skala industri, sehingga pada hasil fraksinasi akan diperoleh minyak yang berkualitas tinggi

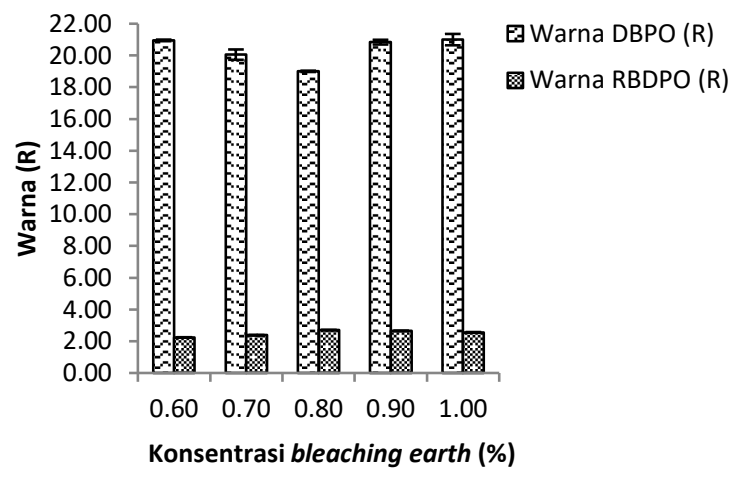

Gambar 4. Efektifitas bleaching earth terhadap warna DBPO dan RBDPO

Konsentrasi Bleaching Earth terhadap Cloud Point Produk

Cloud point (CP) adalah suhu terbentuknya kristal-kristal stearin yang menyebabkan minyak menjadi keruh atau disebut juga dengan derajat kekekuruhan. Minyak yang berkualitas baik tidak akan mengeruh jika disimpan pada suhu normal. Semakin rendah angka cloud point DBPO dan RBDPO, maka semakin tinggi kualitas minyak yang dihasilkan. Berdasarkan hasil yang diperoleh dan disajikan pada Gambar 5, data rata-rata dari 3 batch produksi diketahui nilai cloud point DBPO optimal pada konsentrasi bleaching earth 0,8\% - $0,9 \%$ dengan masing-masing yaitu $2,15 \mathrm{ppm}(\mathrm{SD} \pm 0,06)$ dan 1,95 ppm (SD $\pm 0,03$ ). Untuk cloud point RBDPO pada konsentrasi bleaching earth yang sama yaitu $2,47 \mathrm{ppm}(\mathrm{SD} \pm 0,02)$ dan $1,76 \mathrm{ppm}$ (SD $\pm 0,01)$.

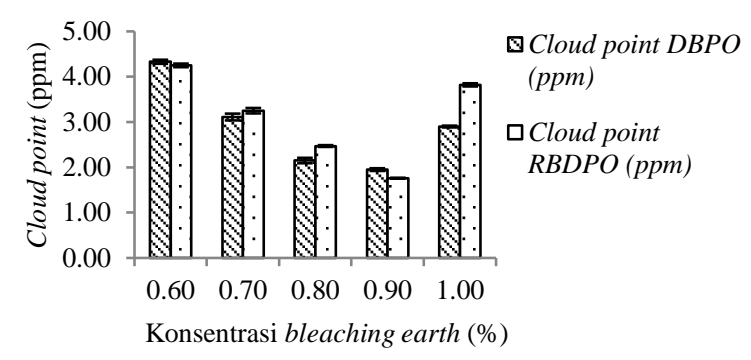

Gambar 5. Efektifitas bleaching earth terhadap cloud point DBPO dan RBDPO

Bahan baku awal (CPO) memiliki ketentuan untuk cloud point tidak melebihi 20 ppm. Sementara ketentuan untuk cloud point DBPO dan RBDPO maksimum 5 ppm. Semakin tinggi cloud point maka semakin tinggi ketidakjenuhan minyak, yang mengakibatkan mudahnya minyak teroksidasi pada saat dilakukan proses produksi (Oboh dan Aworh, 1988).

\section{Konsentrasi Bleaching Earth Terhadap Bilangan Iod}

Salah satu sifat terpenting dari asam lemak adalah tingkat kejenuhannya (degree of saturation) yang dapat ditunjukkan oleh bilangan iod.Minyak dengan bilangan iod yang tinggi memiliki kandungan asam lemak bebas yang tinggi pula (Oboh dan Aworh, 1988). Pada hasil produksi RBDPO, semakin tinggi bilangan iod ( $\mathrm{mg} \mathrm{I}_{2} / \mathrm{g}$ ) maka semakin tinggi asam lemak bebas (FFA), warna menjadi lebih gelap karena teroksidasi dan berpengaruh terhadap cloud point menjadi lebih tinggi (Naghshineh et al., 2010).

Hasil pengukuran bilangan iod pengaruhnya terhadap FFA, warna dan cloud point untuk produk RBDPO disajikan pada Gambar 6 . Mangacu standar kualitas RBDPO pada industri untuk bilangan iod $50-55 \mathrm{mg} \mathrm{I}_{2} / \mathrm{g}$. Berdasarkan data rata-rata dari 3 batch produksi menunjukkan nilai bilangan iod berada pada $51,794 \mathrm{mg} \mathrm{I}_{2} / \mathrm{g}$ hingga $52,775 \mathrm{mg} \mathrm{I}_{2} / \mathrm{g}$ yang berarti bahwa nilai tersebut masih berada pada standar kualitas yang direkomendasikan.Besarnya bilangan iod berbanding lurus terhadap FFA dan warna, yang berdampak pula pada kualitas minyak hasil refinery secara keseluruhan. Bilangan iod terendah pada penambahan konsentrasi bleaching earth 0,8\% $0,9 \%$. 


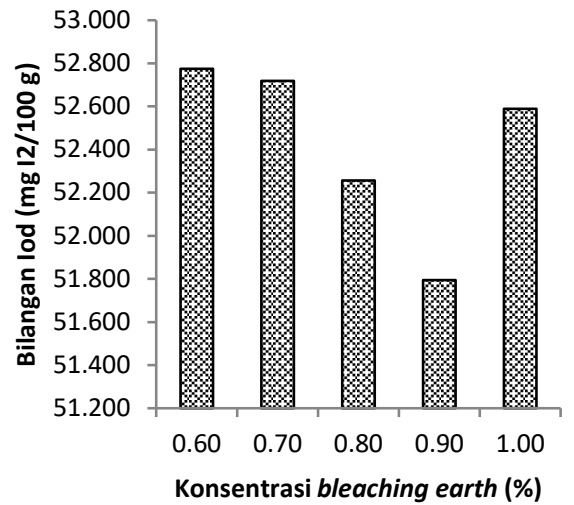

Gambar 6. Efektifitas bleaching earth terhadap keberadaan bilangan iod produk RBDPO

Pada Gambar 7 berikut merupakan kenampakan produk RBDPO hasil dari penambahan bleaching earth 0,8\% - 0,9\%. Hasil tersebut sesuai standar mutu untuk RBDPO meliputi FFA $\leq 0,1 \%$, kadar air dan kotoran berkurang bahkan hingga $0,1 \%$, warna minimum $2,5 \mathrm{R}$, adanya bahan dan senyawa volatil maksimum $0,1 \%$, tidak ditemukan senyawa peroksida dengan bau yang tidak mengganggu (bland). Bilangan iod dari RBDPO tidak melebihi $50-55 \mathrm{mg} \mathrm{I}_{2} / \mathrm{g}$, cloud point tidak melebihi 5 ppm disertai titik leleh pada rentang 33$39^{\circ} \mathrm{C}$. Beberapa faktor yang di analisis memiliki kesamaan dengan SNI : 01- 3741- 2002. Pada akhir proses deodorisasi selain dihasilkan RBDPO juga dihasilkan by product berupa PFAD (palm fatty acid distillatte).

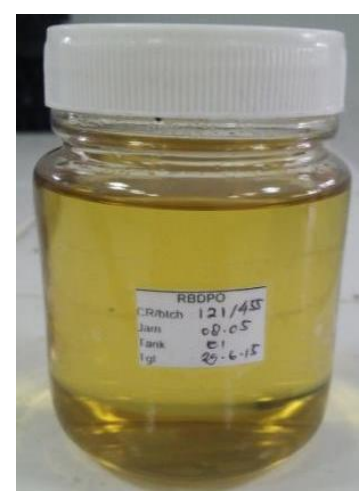

Gambar 7. Kenampakan fisik produk akhir RBDPO

\section{Efisiensi ProsesProduksi}

Dalam industri, target efisiensi dalam proses produksi merupakan sesuatu yang mutlak. Rasio antara ouput dan input menjadi dasar evaluasi kondisi operasional proses yang dijalankan. Ketersediaan bahan baku CPO pada kondisi optimal, optimasi proses dan penambahan berbagai bahan tambahan yang memiliki fungsi khusus, serta ouput dengan sekecil mungkin by waste serta losses yang terjadi menjadi perhatian untuk pencapaian outcome.
Kapasitas 2.000 ton per hari dan penggunaan aktivasi asam pada kondisi yang sama dilanjutkan perlakuan penambahan bleaching earth $0,6 \%-1,0 \%$, pada suhu $100-130^{\circ} \mathrm{C}$ selama 30 menit dengan flow rate rata - rata per jam adalah 41,6 ton, hasil rata-rata dari tiga batch operasi, dicapai efisiensi produksi sebesar 95,51\%. Hasil yang diperoleh sangat relevan jika dihubungkan dengan berbagai parameter kualitas RBDPO lainnya yang diperoleh. Hal ini dikarenakan dari industri refinery tersebut sudah memperhatikan dan menerapkan crititical control point (CCP) dan control point $(\mathrm{CP})$ pada setiap tahapan proses yang diberlakukan (Heryani dan Nugroho, 2017).

\section{KESIMPULAN DAN SARAN}

\section{Kesimpulan}

Berdasarkan hasil observasi dikombinasikan dengan penggunaan data sekunder pada skala industri 2.000 tonper hari, optimasi proses produksi berlangsung pada suhu $100^{\circ} \mathrm{C}-$ $130^{\circ} \mathrm{C}$ dan waktu kontak 30 menit, flow rate rata rata 41,6 ton per jam, memberikan efisiensi proses produksisebesar 95,51\%. Penggunaan konsentrasi bleaching earth optimal 0,8\% - 0,9\% memberikan kualitas FFA pada RBDPO sebesar 0,051 \% $0,053 \%$, warna pada $2,25 \mathrm{R}-2,70 \mathrm{R}$, cloud point 1,76 ppm - 2,47 ppm. Keberadaan bleaching earth pada konsentrasi tersebut menghasilkan angka iod yang standar untuk kualitas RBDPO industri dengan rata-rata $51,794 \mathrm{mg} \mathrm{I}_{2} / \mathrm{g}-52,775 \mathrm{mg} \mathrm{I}_{2} / \mathrm{g}$ dan berbanding lurus terhadap warna dan nilai FFA.

\section{Saran}

Memperhatikan efektifitas pemberian bleaching earth terhadap kualitas DBPO dan RBDPO pada skala industri, disarankan menggunakan konsentrasi bleaching earth 0,8\% $0,9 \%$ agar dicapai efisiensi proses produksi $\geq 95 \%$.

\section{DAFTAR PUSTAKA}

American Oil Chemists' Society. 1998. Official Methods and Recommended Practices of The American Oil Chemists' Society. $5^{\text {th }}$ ed. Urbana: Champaign IL.

Bonnie TY dan Choo YM. 1999. Oxidation and thermal degradation of carotenoid. Journal of Palm Oil Research.II (1): 62-78.

Copeland D dan Maurice BW. 2005. Vegetable Oil Refining. US Patent No: 6844458 B2.

Didi MA, Makhoukhi B, Azzouz A, Villemin D. 2009. Colza oil bleaching through optimized acid activation of bentonite: Acomparative study. Applied Clay Science, 42 :336-344.

Farihahusnah H, Mohamed KA, dan Wan Mohd AWD. 2011. Textural characteristics, surface chemistry and activation of 
bleaching earth: A review. Chem Eng Jour 170 : 90-106.

Gee PT. 2007. Analytical characteristics of crude and refined palm. Eur Journal Lipid Sci Technol. 109: 373-379.

Heryani H dan Nugroho A. 2017.CCP dan CP pada Proses Pengolahan CPO dan CPKO. Yogyakarta: Deepublish.

Ismail MI, Hamidon MH, Zulhilmie M, Sofi M. 2018. Renewable bleaching alternatives (RBA) for palm oil refining from waste materials. Journal Appl Environ Biol Sci. 6(7S): 52-57.

Loh SK, James S, Ngatiman M, Cheong KY, Choo YM, Lim WS. 2013. Enhancement of palm oil refinery waste - spent bleaching earth (SBE) into bio organic fertilizer and their effects on crop biomass growth. Industrial Crops and Products.49: 775-781.

Low K, Lee C, dan Kong L. 1998. Decolorisation of crude palm oil by acid-activated spent bleaching earth. Journal Chem Technol Biotechnol.72: 67-73.

Naghshineh M, Ariffin AA, Ghazali HM, Mirhosseini H, Mohammad AS. 2010. Effect of saturated/unsaturated fatty acid ratio on physicochemical properties of palm olein--olive oil blend. Journal American Oil Chemists' Society. 87(3): 255-262.
Oboh AO dan Aworh OC. 1988. Laboratory trials on bleaching palm oil with selected acidactivated nigerian clays. Journal Food Chemistry. 27: 311-317.

Silva SM, Sampaio KA, Ceriani R, Verh R, Stevens C, Greyt WD, Meirelles AJA. 2014. Effect of type of bleaching earth on the final color of refined palm oil. LWT - Food Science and Technology. 59: 1258-1264.

Tan KH. 1993. Principles Soil Chemistry. $2^{\text {nd }} e d$. New York: Marcel Dekker, Inc.

Tsai WT, Chen HP, Hsieh MF, Sun HF, Chien SF. 2002. Regeneration of Spent Bleaching Earth By Pyrolysis in a Rotary Furnace. Journal Anal Appl Pyrolysis.63: 157-170.

Young FVK. 1987. Palm Oil: Critical Reports on Applied Chemistry. New York: John Wiley and Sons. 